\title{
Between Home and Sufi Convent: Devotional Book Use in Early Modern Damascus
}

\author{
Torsten Wollina
}

\section{1 Introduction}

Research on domestic devotion in premodern Muslim societies is still in its infancy and no study has yet been devoted explicitly to the subject. For instance, Daniella Talmon-Heller laments in her book Islamic Piety in Medieval Syria that the 'regrettable absence of chapters on religiosity at [...] the private home is due to the dearth of relevant source material.'. Nevertheless, she frequently refers to domestic practices throughout the book. Likewise, they have been hinted at for quite some time by historians of architecture, literature, economy, childhood, family, medicine, gender, mysticism, and law.

Lamentation over a lack of certain source genres has accompanied Middle Eastern History from its humble beginnings and is, in the context of domestic practices, readily repeated. Yet, that the home was a site of devotional activities stands to reason. Even religious scholars advised believers to perform certain devotions at home instead of in public places. Women would usually perform their prayers at home. Recent studies by Marion Katz and others have shown both that domestic devotional practices were a ubiquitous - albeit elusive - phenomenon and that they can, to a certain extent, be reconstructed with the help of an eclectic array of sources. ${ }^{2}$ The real issue at hand is not a dearth of sources but a lack of means to access them systematically. Large, even unknown, quantities of pertinent texts remain in manuscript form, held in collections dispersed all over the world and often insufficiently catalogued. This obstacle stands even in the face of current digitization projects, because proper cataloguing and indexing of the digitized manuscripts is often

1 Talmon-Heller D., Islamic Piety in Medieval Syria: Mosques, Cemeteries and Sermons under the Zangids and Ayyubids (1146-1260) (Leiden - Boston: 2007) 2.

2 Katz M., The Birth of the Prophet Muhammad: Devotional Piety in Sunni Islam (London: 2007); Katz M., Prayer in Islamic Thought and Practice (Cambridge: 2013); Katz M., Women in the Mosque: A History of Legal Thought and Social Practice (New York: 2014).

(C) TORSTEN WOLLINA, 2019 | DOI:10.1163/9789004375888_009

This is an open access chapter distributed under the terms of the prevailing CC-BY-NC-ND License at the time of publication. 
neglected due to a lack of funding. This, however, would prove instrumental in order to approach a peripheral research subject such as domestic devotion in any breadth or depth. Otherwise, we run the risk of reproducing the 'publication bias' that results from the fact that a large part of the texts selected to be published in modern editions are focused on political and communal activities, which thus perpetuates the impression that no sources are available to permit adequate study of Muslim domestic devotion.

Yet, even in the published sources, glimpses of domestic devotional activities are relatively frequent, if terse on the actual practices. Legal and advice literature deals with them from a prescriptive position, and even the historiographical genres address them, at least as far as they were of general interest: in cases of illicit behaviour, 'strange occurrences' (ajä̀ib/gharāàib), or semi-public rituals (wedding, childbirth, death, reception of guests), their gaze turns towards domestic settings. ${ }^{3}$ Partly drawing on these sources, Katz has shown that the mawlid festivities on the Prophet's birthday were from early on also celebrated in domestic settings. By the fifteenth century, the mawlid had also become 'a common, although far from universal, component' of wedding and circumcision festivities. ${ }^{4}$

Katz brings to light a crucial source for our topic: the journal the fifteenthcentury Damascene notary Ahmad Ibn Țawq (d. 1509) kept for over twenty years $(1480-1501) .^{5}$ Neither an important nor a remarkable person himself, Ibn Tawq stands out from his contemporaries in that he kept his journal diligently and in that it actually survived despite never being bound in a codex. As a unique example of a probably much wider cultural practice, ${ }^{6}$ it offers insights into many aspects of domestic devotion, including the age-old custom that a pious man should sleep in the bed of newly-weds for three days before their wedding, and domestic prayers and Qurān recitations in the house of his

3 For one exception, see Guo L., “Al-Biqā̄î̀s Chronicle: A Fifteenth Century Learned Man's Reflection on his Time and World", in Kennedy H. (ed.), The Historiography of Islamic Egypt (c. 950-180o) (Leiden - Boston: 2001) 121-148; Guo L., "Tales of a Medieval Cairene Harem: Domestic Life in al-Biqāī’s Autobiographical Chronicle", Mamlūk Studies Review 9, 1 (2005) 101-121.

4 Katz, The Birth of the Prophet 67, 70, citation from 72.

5 Wollina T., "Ibn Tawq's Ta'līq. An Ego-Document for Mamlūk Studies", in Conermann S. (ed.), Ubi Sumus? Quo Vademus? Mamluk Studies - State of the Art, Mamluk Studies 3 (Göttingen: 2013) $337-362$.

6 Makdisi G., "The Diary in Islamic Historiography: Some Notes", History and Theory 25, 2 (1986) 173-185; Wollina T., "The Samuel Pepys of Damascus? Ahmad Ibn Țawq and the Arabic Diary Tradition", paper presented at the Second Annual Symposium on Medieval and Renaissance Studies, St. Louis University, 19 June 2014. 
mentor and relative (through marriage) Taqī al-Dīn Ibn Qāḍī 'Ajlūn. ${ }^{7}$ An account of deathbed piety stands out for the intensity of the emotions it conveys. This is the description of the rituals Ibn Tawq and others performed in the last hours of Muhibb al-Dīn, a cousin of Taqī al-Dīn:

In the morning, Qāọī Muhibb al-Dīn lay on his deathbed (dīwān almuhtadirīn). He died shortly before sunset. I entered with Kamāl al-Dīn [and four other persons]. We recited for him the Sūra [Yā-sīn] and performed the dhikr [ritual invocations of God's names]. Then I stepped outside. My compassion was too great to look at him. There I encountered the shaykh [Taqī al-Dīn] who had just arrived. I pulled him down to sit on the bench. Then [Muhibb al-Dīn] died, may God be merciful with him!

The instances in which Ibn Țawq addresses domestic devotion usually appear isolated and mostly stand apart from the rather communal focus of his journal. Often his accounts are restricted to a (selective) list of attendants or/and dishes served, if the occasion was a festive one. This article, however, will address Ibn Tawq's reports on devotional usages of books or texts. Although he rarely addresses the issue directly, his notes on book circulation allow conclusions about how devotional book use connected devotional practices in domestic and other settings. Moreover, he gives insight into a rather ubiquitous circulation of objects, which is occasionally hinted at in other sources as well. As indicated above, devotional use of books was considered by religious scholars as something that could be beneficial as well as detrimental to the community of believers. Domestic book use by laypeople was regarded as potentially dangerous if not guided by the knowledgeable. On the other hand, to a large extent, domestic book use depended on endowed libraries, which were usually lending libraries, offering access to (devotional) books to a larger public. It is in this context that we should evaluate Ibn Țawq's reports on the subject.

The emergence of 'published' prayer books seems to have occurred contemporaneously with the rise of the mawlid and Prophetic devotion more generally. ${ }^{9}$ The genre's most successful emanation was certainly the Daläil alKhayrāt by the Maghribī Sufi al-Jazūlì (d. 1465-70), which reached the eastern

7 Ibn Ṭawq Shihāb al-Dīn Aḥmad, Al-Tálīq. Yawmiyyāt Shihāb al-Dīn Aḥmad Ibn Tawq. Mudhakkirāt kutibat bi-Dimashq fì awākhir al-'ahd al-mamlūkī, ed. J. al-Muhājir, 4 vols. (Damascus: 2000-2007) vol. 1, 548; vol. 2, 584 .

8 Ibn Țawq, al-Tacì $q$ vol. 2, 615 .

9 For examples or precursors from the thirteenth and fourteenth centuries, see Katz, The Birth of the Prophet 144; Ibn al-'Arabī, Muhyī al-Dīn, The Seven Days of the Heart. Awrād al-usbū' 
half of the Mediterranean only by the middle of the seventeenth century, but by the nineteenth century was known as far away as Indonesia. The Daläil is clearly 'organised as a manual for Muhammad devotion. ${ }^{10}$ Throughout it features full vocalization to enable correct reading. It states itself that it omits the 'chain of transmission, [so] it becomes easier to master [the prayers] in recitation, and [recitation] is most important in coming close to the Lord of the two worlds. ${ }^{11}$ Starting in the seventeenth century, copies also contained illustrations of the Prophet's grave in Medina and later also the Ka'ba in Mecca [Fig. 7.1]. In their design these prayer books clearly point towards a new quality of Muslim domestic devotion in the Ottoman period, which has not yet been examined beyond the Dalä $i l$ itself. ${ }^{12}$

The Dalä'll was predated by other devotional texts concerned with the veneration of the Prophet. ${ }^{13}$ The so-called Mantle Ode (qașidat al-burda), a praise poem by al-Būṣīīi (thirteenth century), has been identified as a central text for domestic devotion (not only) in Early Modern Cairo. ${ }^{14}$ A decisive difference between this and the later work was, however, that the latter is 'provided with detailed instructions for the reader telling him how to handle the book. Ritual purity before reading is one of them; the way of holding the book in one's hands is another'. ${ }^{15}$ As Ibn Țawq's account will show, these issues were in his time to be negotiated with recourse to different works and even genres. In this, books were never completely disentangled from the direct/oral

(Wird): Prayers for the Nights and Days of the Week, trans. P. Beneito - S. Hirtenstein (Oxford: 2008).

10 Witkam J.J., "The Battle of the Images: Mekka vs. Medina in the Iconography of the Manuscripts of al-Jazūlī's Dalā'il Al-Khayrät", in Pfeiffer J. - Kropp M. (eds.), Theoretical Approaches to the Transmission and Edition of Oriental Manuscripts: Proceedings of a Symposium Held in Istanbul, March 28-30, 2001, Beiruter Texte und Studien 111 (Beirut: 2007) 67-82, 295-300, here 69.

11 Al-Jazūlī Muḥammad b. Sulaymān, al-Kitāb dalāil al-khayrāt wa-shawāriq al-anwār fì dhikr al-șalāt 'alā al-nabī al-mukhtār, MS Smith 135, Rare Book \& Manuscript Library, Columbia University in the City of New York fols. 1b-2a.

12 Frederike-Wiebke Daub's published dissertation casts new light on how these texts were intended to be read; Daub F., Formen und Funktionen des Layouts in arabischen Manuskripten anhand von Abschriften religiöser Texte: al-Būșîrīs Burda, al-Ğazūlīs Dalā’il und die Šifä̀' von Qādì 'Tyā d (Wiesbaden: 2016).

13 See, for example, the percentage of prayer books contained in one thirteenth-century library: Hirschler K., Medieval Damascus: Plurality and Diversity in an Arabic Library: The Ashrafiya Library Catalogue (Edinburgh: 2016).

14 Abou-Khatwa N., "An Ode to Remember: The Burda of Al-Busiri in Cairene Ottoman Houses", in Kane B. (ed.), Creswell Photographs Re-examined: New Perspectives on Islamic Architecture (Cairo: 2009) 43-69.

15 Witkam, "The Battle of the Images" 70. 


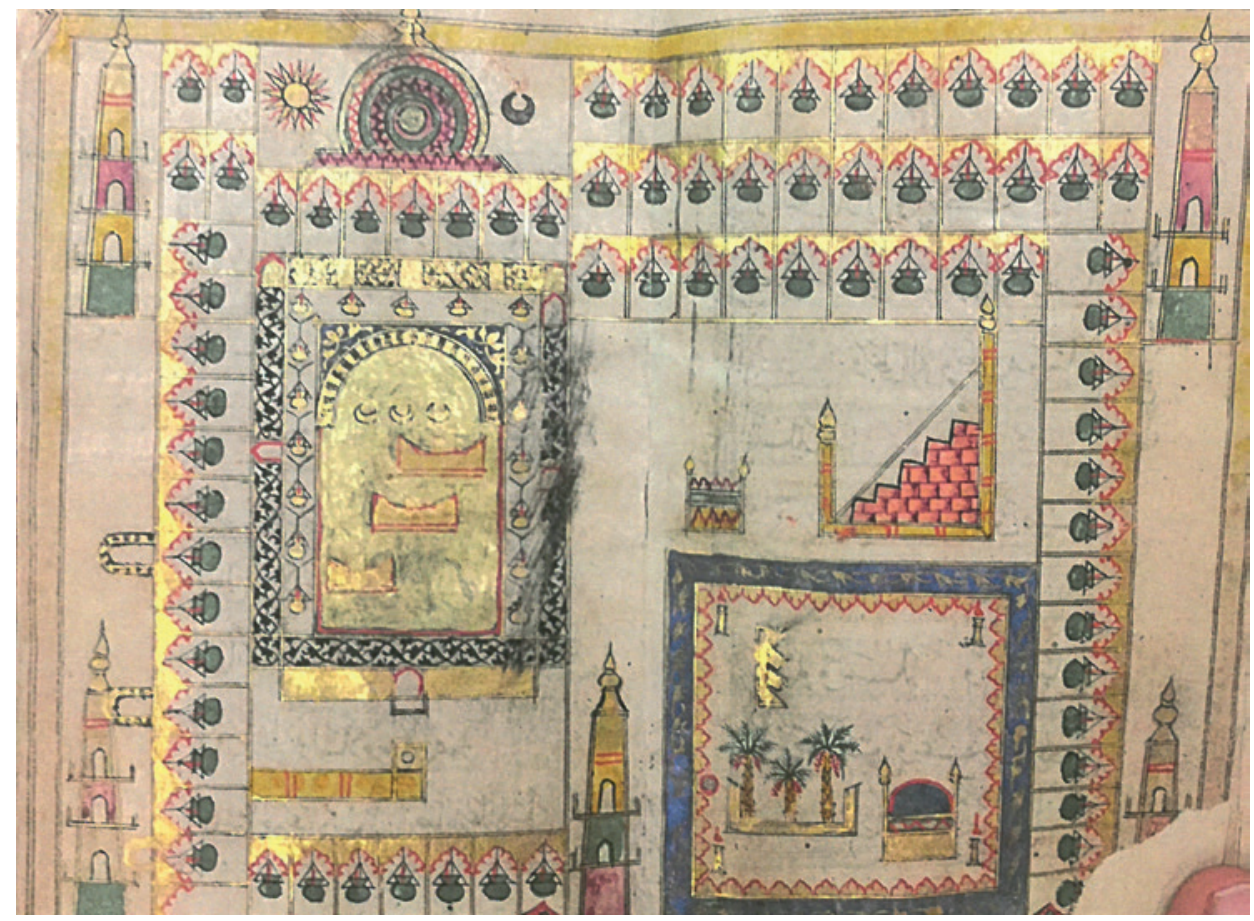

FIGURE 7.1 Anonymous, "The Prophet's grave and mosque in Medina” (18th century?). Rare Book \& Manuscript Library, Columbia University in the City of New York, MS Smith 217 , fols. $27 \mathrm{~b}-28 \mathrm{a}$

IMAGE (C) RARE BOOK \& MANUSCRIPT LIBRARY, COLUMBIA UNIVERSITY IN THE CITY OF NEW YORK

transmission of knowledge (from master to student); rather, their circulation in part depended on - and reproduced - these very networks.

Thus, devotional book use was never an exclusively domestic phenomenon, but needs to be seen within a nexus of practices involving different domestic and communal - sites of devotion, first among them educational and devotional institutions (mosque, madrasa, zäwiya). Book circulation connected communal and domestic spaces.

\section{How to Approach Muslim Domestic Devotion?}

To the best of my knowledge, spatial differentiation played in general a minor role in Muslims' choices of devotional spaces. While the observance of obligatory prayers at a mosque was recommended for all male adults, only 
attendance at the Friday prayer should be seen as mandatory. This is reflected in Ibn Tawq's journal, as he frequently notes where he observed this prayer and who gave the sermon (khutba). He also tells us that on some days 'I did not go to the city today' or that his mentor Taqi al-Dīn spent whole days in his house after quarrels with his Egyptian wife. ${ }^{16}$ They would then observe their obligatory prayers (as well as other devotions) at home.

The distinction between the profane and the sacred was not constituted by way of spatial separation but rather by the deliberate pronunciation of words. The utterance of precise devotional phrases, embedded in strict ritual acts, 'shuts off the prayer-time as sacred, and makes unlawful all ordinarily right acts, only the acts and words of the set prayer being permitted.1 ${ }^{17}$ Also, the Sufi practice of dhikr aimed at an individual 'state of inward recollectedness' through collective 'recitations of certain fixed phrases [...] in a given order'.18 The great mystic Ibn al-Arabī's prayers for the seven days of the week (awräd $a l-u s b \bar{u}$ ), supposedly intended for 'private and intimate' devotion, were also to be recited, if only in a mutter. ${ }^{19}$

Supplicatory devotions were only valid if they built upon the 'pillars of the faith'. One intriguing case is related by the biographer Najm al-Dīn al-Ghazzī in two separate accounts. It revolves around the interpretation of a dream by the sixteenth-century Damascene polymath Muhammad Ibn Tuulūn (d. 1546). The following rendition switches between both accounts:

Ibn Ṭūlūn used to visit [shaykh Sulaymān] frequently and trusted him. One time a Sufi approached shaykh Sulaymān, asking him: 'Oh sīdī ('sir'), I have seen the Prophet in a dream and he had black skin'. Shaykh Sulaymān spoke: 'Here is our mawlā (teacher) shaykh Shams al-Dīn; he will interpret this dream for you'.

Ibn Țūlūn answered: 'This dream points out that the dreamer disagrees with the sunna [i.e. The Prophet's precedent], because [the Prophet] had white skin and the black colour contradicts his colour. Therefore, the dreamer contradicts the sunna'. The man sought protection from that and said: 'Not one thing of that is my belief'.

And the shaykh [Sulaymān?] told him: 'Certainly you violated the sunna a bit? And it is not certain that you have to repent for it'. And [the

$16 \quad$ E.g. Ibn Ṭawq, al-Ta lì q vol. 1, 170.

17 Padwick C.E., Muslim Devotions: A Study of Prayer-Manuals in Common Use (London: 1961) 34 .

18 Padwick, Muslim Devotions 14-15.

19 Ibn al-'Arabī, Seven Days 2. 
Sufi] spoke: 'I myself know nothing about that except maybe I was too occupied to observe the prayer (șalät)'.

And the shaykh [Ibn Țūlūn] told him: 'Oh praised be God, but which divergence from the sunna could be greater than this one? Abandoning the prayer is one of the greatest crimes! This results in the black face. As it says in the hadith: "he who prays at night has a beautiful face during the day, but he who abandons the prayer, his face blackens"'. Now, the man wept and the shaykh made him repent. ${ }^{20}$

Whatever the historical accuracy of the account, it is certainly a powerful moral tale. The inquiring Sufi, who ranked mystic forms of devotion above the obligatory prayers, was harshly reprimanded not only by the shaykhs but also, in a way, by the Prophet himself. In contrast, a certain shaykh Ma'rūf had dedicated his whole life to devotion, the feeding of the poor and garden work ('amal al-basātīn), and would even climb the city gates to make sure he did not miss the obligatory prayers at the central Umayyad Mosque. His piety was rewarded when one night he was visited by the Prophet himself. Moreover, the Prophet licked from a bowl of honey in Ma'rūf's house. Miraculously, the honey remained, and henceforth Ma'rūf offered it to all 'Qur'ān reciters and jurists' who would call on him. ${ }^{21}$ The relevant hierarchy was thus not between communal and domestic sites of devotion but between obligatory and supplicatory devotions, and domestic practices would often have corresponded to communal rituals at other sites.

On the other hand, educational and devotional institutions (madrasa, Sufi convent, mosque) included somewhat 'domestic' spaces as well. Descendants of the founder and other beneficiaries might have their residence there, and in his influential manual on the conduct of scholars and students, Badr al-Dīn Ibn Jamāaa (1241-1333) ascribes certain 'domestic' qualities to the cells (khalwa) where teachers and students lived. ${ }^{22}$ They were also important sites of book circulation and book use, which are difficult to disentangle from domestic settings. Sessions of Prophetic traditions (hadith) were frequently held in private

20 This version has been collated from both accounts in favour of a more lively description: al-Ghazzī, Najm al-Dīn Muhammad: al-Kawākib al-sā̉ira bi-a'yān al-mi'a al-āshira, ed. J. Jabbūr, 2 vols. (Beirut: 1945) vol. 2, 53, 148.

21 Al-Bușrawī 'Alā' al-Dīn, Tārīkh al-Bușrawì șafahạat majhūla min tārīkh Dimashq fì 'aṣr Almamālīk (min Sanat 871 H li-ḡāyat 904 H), ed. A. al-'Ulabī (Damascus: 1988) 42.

22 E.g. Ibn Ṭawq, Al-Ta ‘̄̄q vol. 3, 1534; Ibn Jamāaca, Badr al-Dīn Muhammad, Kitāb kifāyat almutakallim $f \grave{i}$ adab al-'álim wa-l-muta'allim, X-Series, MS X893.7 Ib65 (1), Rare Book \& Manuscript Library, Columbia University in the City of New York fol. $48 \mathrm{~b}$. 
homes, in particular when they were taught by female transmitters. ${ }^{23} \mathrm{Ibn}$ Tawq was present when one Ibn al-'Ullāf was examined on works of grammar and Qur'ānic recitation in his mother's house $\left(q \bar{a}^{c} a\right)$ and received general approval and 100 dirham for his presentation. ${ }^{24}$ Teaching and examination of students, in particular, seems to have followed set procedures, which allows us to close gaps that otherwise would remain obscure. Ibn al-'Ullāf's examination might thus have resembled another in the Shāmiyya al-Barrāniyya madrasa. There, the above-mentioned Taqī al-Dīn posed forty questions on hadìth to his student 'Abd al-Raḥmān al-Ṣaffūrī (apparently in writing), on which he would be examined the next day. The student would recite the questions and his answers from his notes (kurrās/kurrāsa) and comment upon them. Afterwards, the scholars present would examine his reading and answers. ${ }^{25}$

Educational and devotional book use cannot be completely separated from each other since the search for knowledge (talab al-ilm) was every believer's obligation (although books were not always perceived as the means to achieve it). ${ }^{26}$ They also shared a sacralization of book use, both in reading and writing:

$[\mathrm{I}] \mathrm{t}$ is necessary that you are in a ritually clean state. Thus turn your face to the qibla, body and clothes clean, and write every book beginning with "bi-smi-llāh al-rahmān al-rahīm" ['in the name of God the all-merciful']. The book begins with a sermon to thank God and the prayer for the Prophet - write this after the basmalla. Only then write what the book is about. The same is done at the end of the book and at the end of each $j u z$ ' [quire/section/volume], until the book is finished [...]. ${ }^{27}$

23 Sayeed A., "Women and Ḥadīth Transmission. Two Case Studies From Mamluk Damascus", Studia Islamica 95 (2002) 71-94.

24 Ibn Ṭawq, Al-Ta līq vol. 1, 533. In one biographical work, Ibn Ṭūlūn mentions tens or even hundreds of other occasions of devotion and learning taking place in private houses; "Dhakhāir al-qașr fī tarājim nubalā' al-'așr", Forschungs- und Landesbibliothek Gotha, MS Orient A 1779 .

25 Ibn Ṭūūn Shams al-Dīn Muhammad, Mufäkahat al-khillān fì hawādith al-zamān: Tärīkh Mișr wa-l-Shām, ed. M. Mușțafā (Cairo: 1964) vol. 1, 88.

26 Liebrenz B., Die Rifǟāya aus Damaskus: Eine Privatbibliothek im Osmanischen Syrien und ihr kulturelles Umfeld (Leiden: 2016) 4-11.

27 Ibn Jamāca, Kitāb Kifāya, fols. 39b-40a. Cf. Sadan J., "New Materials Regarding Purity and Impurity of Books in Islam in Comparison with Judaism. Al-Burzulī and Other Muslim Scholars on Defiled Parchment, Papyrus and Paper",Jerusalem Studies in Arabic and Islam 33 (2007) 193-218. 
Texts were first to be studied under a master to ensure that they were understood in the right way, and even so, unsupervised book use could be a 'source of anxiety and censure'.28 Ibn Tawq's account does not address this issue but it betrays a comparable veneration for the objects. Books that were left with him to be delivered to their owner he therefore kept in his cell (khalwa), where they were safer than in the buzz of his household. ${ }^{29}$ Others he purposefully brought to his home, for they were valued for qualities beyond their content. His exclamation that 'may God be merciful to the authors and the donors' indicates that the collection and endowment of books was valued almost as much as the writing of new ones. ${ }^{30}$

Book Circulation in Damascus

Book circulation rested on three pillars: the local book market east of the Umayyad Mosque - virtually absent from Ibn Tawq's journal, educational and devotional institutions, and private collections. As mentioned above, religious institutions were the heavyweights in the local production, transmission, and distribution of (devotional) books. In the Dār al-Hadìth al-Ashrafiyya, a thirteenth-century foundation dedicated to the teaching of Prophetic traditions, a librarian was tasked with the restoration of bindings and individual folios, and decisions about the acquisition and reproduction of texts lay with the highest offices: the shaykh and the supervisor. At specific times, copying by students was supported by provision of writing tools, paper, and even stipends and food. ${ }^{31}$ Even many smaller institutions had a librarian who took account of in - and outgoing books. ${ }^{32}$

These institutions were also preferred repositories of books. One generation after Ibn Țawq, the polymath Ibn Ṭūlūn remarks that the important Abū 'Umar madrasa housed some of the most important endowed collections:

28 El-Rouayheb K., "The Rise of 'Deep Reading' in Early Modern Ottoman Scholarly Culture", in Pollock S. - Elman B.A. - Chang K.K. (eds.), World Philology (Cambridge - London: 2015) 201-214, here 201.

29 Explicitly: Ibn Țawq, Al-Ta līq vol. 1, 337; Implicitly: Ibn Țawq, Al-Ta līq vol. 4, 1556.

3о Ibn Țawq, Al-Talīq vol. 3, 1098.

31 Ibn Ṭūlūn Shams al-Dīn Muḥammad, al-Lamacāt al-barqiyya fì al-nukat al-tārīkhìyya, ed. Șalāḥ al-Dīn al- Munajjid (Damascus: 1929) 23-24.

32 Hirschler K., The Written Word in the Medieval Arabic Lands: A Social and Cultural History of Reading Practices (Edinburgh: 2012) 138. 
In this madrasa, a number of people have endowed their book cases (libraries), the most exalted of which are the books of the sayyid [Kamāl al-Dīn or 'Izz al-Dīn] al-Ḥusaynī. Others are the books of shaykh Qiwām al-Dīn al-Ḥanafî, Shams al-Dīn al-Bānyasī, the traditionary Jamāl al-Dīn Ibn 'Abd al-Hādī, Shihāb al-Dīn Ibn Manșūr and the Dīwān al-Jaysh Badr al-Dīn. Among these books is the Qur'ān copy (mușhaf) in the handwriting of the Imām 'Alī Ibn Abī Ṭālib [the Prophet's son-in-law]. ${ }^{33}$

As this quote indicates, the importance of an endowed library to a large extent depended on private efforts of book collection. The individuals mentioned had first accumulated considerable collections before they endowed a library. Private initiative was also essential in transporting books between places. The introduction of a work from a distant place - or the distant past - was often celebrated by biographers as much as the publication of an original work. The above-mentioned Kamāl al-Dīn al-Ḥusaynī was thus credited for bringing a commentary by one of his Egyptian teachers to the attention of scholars in Damascus. ${ }^{34}$ A certain Maḥmūd al-Shīrāzī introduced to Syria excerpts from commentaries of twelve East Anatolian scholars he had jotted down in his copy of Ḥusayn al-Baghawì's (d. 1117 or 1122) hadìth collection Mașābịh alsunan: 'All these works were in that period available in the lands of the Kurds but rarely in the Lands of the Arabs' ${ }^{35}$ One Ahmad al-Kūrānī (b. 809/1406-7) endowed his own publications in Damascene institutions, even after he had migrated to Anatolia. ${ }^{36}$ Ibn Ṭūlūn's own fame as a, if not the historian of his era, rested to a high degree on his rediscoveries and summaries of obscure works by almost forgotten scholars. ${ }^{37}$ His works furthermore include hints that his research was not restricted to endowed libraries but took him into people's private collections as well.

Judging by Ibn Tawq's account, the local circulation of devotional texts rested to a considerable degree on privately owned copies, but they were not necessarily the individual user's property. Rather, they would often be away

33 Ibn Ṭūlūn Shams al-Dīn Muhammad, al-Qalāìd al-jawhariyya fì tārīkh al-Ṣālihịya, ed. M. Duhmān et al., 2 vols. (Damascus: 1949-56) vol. 1, 273-274.

34 For his biography, see Ghazzī, al-Kawākib vol. 1, 40-46.

35 Ghazzī, al-Kawākib vol. 2, 249.

36 For his biography, see Ibn Ṭūlūn Shams al-Dīn Muhammad, al-Ghuraf al-Āliyya fì Tarājim Muta’akhkhirī al-Ḥanafiyya, Istanbul, Süleymaniyye Library, MS Şehid Ali Paşa 192 fols. $47 \mathrm{~b}-48 \mathrm{~b}$.

37 Perhaps the best example is his work on governors of Damascus since the Mongol invasion (1260), more than half of which is an abridged copy of an earlier account: Ibn Țūlūn Shams al-Dīn Muhammad, I'lām al-warā bi-man waliya nā̉iban min al-Atrāk bi-Dimashq al-shām al-kubrā, ed. M. Duhmān (Damascus: 1984). 
from their owner as long-time borrowings between the homes of friends and family members.

\section{$4 \quad$ Ibn Ṭawq on Book Circulation}

Ibn Țawq's journal is an exceptional text in that it is not exclusively concerned with the extraordinary or unexpected, but addresses some of the very secular practices that constituted the everyday. Book use and exchange were clearly part of this lived reality. Yet, his treatment of these affairs is often rather nonchalant and explanations are few. Ibn Tawq does not speak about reading experiences or devotional engagement but only mentions books when they are purchased, borrowed, copied, or delivered. Furthermore, the sample is uneven: sold books are only named when the author was present for the sale, nor does he always explain why he delivered a book - had he borrowed it for himself or did he return it for another peruser? Moreover, Ibn Țawq uses abbreviates titles for many works, often without giving an author, which repeatedly creates ambiguities about the works' identities and subjects. To give but one example, the title 'al-Tahdhīb' (mentioned below) could refer to a collection of biographies by the thirteenth-century historian al-Dhahabì (Tahdhìb al-tahdhīb) but also to a biography of the Prophet by the fourteenth-century scholar Ibn Kathīr (Tahdhïb sïrat Ibn Kathïr) or to a hadith compilation by the fifteenthcentury jurist Ibn Hajar al-'Asqalānī (also Tahdhīb al-tahdhīb). My conclusions therefore have to depend on circumstantial information and might be faulty. In the following tables, a question mark indicates where I am uncertain about the identity of a work or author.

Within the twenty-year period covered by the journal, I have identified eighteen cases of book circulation, which include about thirty intellectual works and more than forty individual items. Among them are one entry on book confiscation, four on purchases (three of which are connected to inheritance); but ten on borrowing, only two of which were explicitly connected with making new copies (although more indicate the same aim). One entry refers to the compilation of a new work. ${ }^{38}$ The pervasive presence of devotional texts attests to the scholarly and Sufi-inclined circles in which Ibn Țawq moved: in addition to the Quraan, the largest share of the sample is made up by a large number of books about the Prophet - his biography, discussions about his qualities, and praise poems for him, collections of prayers, legal texts that dealt with ritual and ablution, and biographies of pious and erudite people from earlier

38 Ibn Ṭawq, Al-Ta lì q vol. 2, 842 . 
generations. ${ }^{39}$ In contrast, Ibn Țawq dismisses books sold from the inheritance of a deceased emir as of little worth: 'Most of them are boastful epics ( fashārāt $)$. Among them was [even] the [historical epos] Sirrat 'Antara'.40

While this sample might still seem meagre, it should be understood as the tip of the iceberg and allows for conclusions about the wider circulation of books. First, many of the books Ibn Tawq identifies circulated within a very exclusive circle of fewer than ten people who were connected to each other by kinship ties and/or teacher-student relations. Whereas the aural/oral transmission of knowledge established - sometimes lifelong - relationships, book loans apparently presupposed those. Such an exchange depended on close social contacts, both because of a book's material value and because of the need to assess a user's ability to comprehend a book. The central figure for the author's network was the above-mentioned Taqī al-Dīn Ibn Qādī 'Ajlūn who exchanged nine items in four entries, but through whom Ibn Tawq was connected to other important book owners: Taqī al-Dīn's students Shams al-Dīn al-Kafarsūsī (1 entry/4 items) and Sirāj al-Dīn al-Ṣayrafì (1 entry/ 2 items), and his nephew Kamāl al-Dīn al-Ḥusaynī, who purchased another ten books for the large sum of 4680 silver dirham ( fidd da) [See table 1] ${ }^{41}$ Kamāl al-Dīn's brother-in-law Abū al-Faḍl Ibn Imām had Ibn Ṭawq copy parts of the Prophet's biography. ${ }^{42}$ Finally, after Kamāl al-Dīn had suffered some hardships by the hands of the governor, Ibn Tawq brought to his house his own copies of the Mantle Ode and the Kitāb al-Shifä, two texts that should comfort him and give him strength to face these adversities. ${ }^{43}$

Secondly, loans were an important means of gaining access to (certain) books, sometimes for months at a time, and so allowing for intense engagement with them. Overall, only in six entries can items be identified as the property of endowed libraries, and in nine as private property, six of them purchases, confiscations, and compilations of previous books to make a new one. In the remaining cases, all concerning book loans, ownership remains uncertain. In this context, possession of a book was more important for Ibn Ṭawq than ownership. Access to these books seems to have been curtailed along educational hierarchies, so that one might need an interlocutor (e.g. one's shaykh)

39 Biographical literature 'defends, and of course defines, the tradition' that establishes correct devotions; Calder N., "Law", in Nasr S.H. - Leaman O. (eds.), History of Islamic Philosophy (London: 1996) 979-998, here 982.

$40 \quad$ Ibn Țawq, Al-Ta lì $q$ vol. 1, 268. The other one is found at p. 289.

41 Ibn Țawq, Al-Ta'lïq vol. 1, 263-264.

42 Ibn Țawq, Al-Ta'lī vol. 1, 350.

43 Ibn Ṭawq, Al-Ta lì $q$ vol. 2, 905. 
TABLE 7.1 Books sold, based on Ibn Ṭawq, al-Ta līq vol. 1, 263-264; vol. 4, 1659

\begin{tabular}{|c|c|c|c|c|}
\hline $\begin{array}{l}\text { Title } \\
\text { (author/copyist) }\end{array}$ & Subject & Seller & Buyer & $\begin{array}{l}\text { Price } \\
\text { (in dirham) }\end{array}$ \\
\hline $\begin{array}{l}\text { Tahdhīb [sīrat Ibn } \\
\text { Kathīr?] (Ibn Kathīr?/ } \\
\text { Ibn Raslān) }\end{array}$ & $\begin{array}{l}\text { biographies of } \\
\text { traditionaries }\end{array}$ & $\begin{array}{l}\text { Ibrāhīm } \\
\text { al-Qudsī }\end{array}$ & $\begin{array}{l}\text { Kamāl al-Dīn } \\
\text { al-Húsaynī }\end{array}$ & 600 \\
\hline $\begin{array}{l}\text { Mukhtașar sharḥ } \\
\text { lāmiyyat al-'ajam } \\
\text { (al-Ṣafadī?) }\end{array}$ & $\begin{array}{l}\text { Poetry, } \\
\text { commentary, } \\
\text { summary }\end{array}$ & $\begin{array}{l}\text { Ibrāhīm } \\
\text { al-Qudsī }\end{array}$ & $\begin{array}{l}\text { Kamāl al-Dīn } \\
\text { al-Ḥusaynī }\end{array}$ & 100 \\
\hline $\begin{array}{l}\text { 5x Sharḥ al-Bukhārī } \\
\text { (Ibn Ḥijjī/Shams } \\
\text { al-Dīn al-Qudsī) }\end{array}$ & $\begin{array}{l}\text { Hadīth, } \\
\text { commentary }\end{array}$ & $\begin{array}{l}\text { Ibrāhīm } \\
\text { al-Qudsī }\end{array}$ & $\begin{array}{l}\text { Kamāl al-Dīn } \\
\text { al-Ḥusaynī }\end{array}$ & $\begin{array}{l}\text { [sold in } \\
\text { bulk for } \\
35^{88} \text { ] }\end{array}$ \\
\hline $\begin{array}{l}\text { Sharḥ al-Bukhārī } \\
\text { (al-Barmāwī/Shams } \\
\text { al-Dīn al-Qudsī) }\end{array}$ & $\begin{array}{l}\text { Hadith, } \\
\text { commentary }\end{array}$ & $\begin{array}{l}\text { Ibrāhīm } \\
\text { al-Qudsī }\end{array}$ & $\begin{array}{l}\text { Kamāl al-Dīn } \\
\text { al-Ḥusaynī }\end{array}$ & $\begin{array}{l}\text { [sold in } \\
\text { bulk for } \\
35^{88} \text { ] }\end{array}$ \\
\hline $\begin{array}{l}\text { Sharh al-Bahja [of Ibn } \\
\text { al-Wardī] (al-Anșārī?/ } \\
\text { Shams al-Dīn al-Qudsī) }\end{array}$ & $\begin{array}{l}\text { Law, } \\
\text { commentary }\end{array}$ & $\begin{array}{l}\text { Ibrāhīm } \\
\text { al-Qudsī }\end{array}$ & $\begin{array}{l}\text { Kamāl al-Dīn } \\
\text { al-Ḥusaynī }\end{array}$ & $45^{0}$ \\
\hline $\begin{array}{l}\text { [Kitāb al-] Adhkār } \\
\text { (al-Nawawī/Ibn Raslān) }\end{array}$ & $\begin{array}{l}\text { Dhikr, } \\
\text { prayers }\end{array}$ & $\begin{array}{l}\text { Ibrāhīm } \\
\text { al-Qudsī }\end{array}$ & $\begin{array}{l}\text { Kamāl al-Dīn } \\
\text { al-Ḥusaynī }\end{array}$ & 150 \\
\hline Qurāan & Qurān & $\begin{array}{l}\text { [a young } \\
\text { man from } \\
\text { al-Bajadaliyya] }\end{array}$ & $\begin{array}{l}\text { Muḥsin } \\
\text { al-Turkmānī } \\
\text { al-Qābūn̄̄ }\end{array}$ & 121 \\
\hline Qurān & Qur’ān & - & $\begin{array}{l}\text { Muhsin } \\
\text { al-Turkmān̄̄ } \\
\text { al-Qābūnī }\end{array}$ & 140 \\
\hline
\end{tabular}

to obtain a book. Endowed libraries seem to have granted loans of their books only to a restricted circle:

I delivered to Zayn al-Dīn 'Abd al-Raḥmān al-Ba'alī the last [part] of Maqbül al-manqül which he had borrowed for me [last year] from the shaykh of the zāwiya, al-Bānyāsì's son, and along with those two other volumes. I had quickly sent them back to Zayn al-Dīn, but this one stayed with me. I returned it to him today; this shall be known! ${ }^{44}$ 
Likewise, Taqī al-Dīn Ibn Qāḍī 'Ajlūn, who held an important teaching post in the Umayyad Mosque, was in the position to permit the loan of a twohundred-year-old Qurān. ${ }^{45}$ In another case, he loaned a book from a Sufi convent that Ibn Tawq delivered to the stepson of shaykh Ibn Dāwūd (whose daughter had married his cousin) when they met in Kamāl al-Dīn's house. ${ }^{46}$ Thus, the exchange of books relied on and, at the same time, reinforced networks of kinship and hierarchies of knowledge. Although it is not explicitly stated, this practice served to control who was allowed to read what and who was not deemed ready. Domestic use of books thus depended on earlier mastering of these texts in a more controlled educational setting. ${ }^{47}$

TABLE 7.2 Borrowed works (Titles as found in the text plus additions to identify them)

\begin{tabular}{|c|c|c|c|}
\hline Title (author) & Subject & Items & Vol./Page \\
\hline Qurān & Qurān & bound vol. & II/906 \\
\hline $\begin{array}{l}\text { Sīrat Ibn Sayyid al-Nās } \\
\text { (Muhạammad al-Ya’mūrī) }\end{array}$ & The Prophet's biography & parts (1st) & III / 1098 \\
\hline $\begin{array}{l}\text { al-Sīra al-nabawiyya } \\
\text { (Ibn Hishām or Ibn Kathīr) }\end{array}$ & The Prophet's biography & $\begin{array}{l}\text { parts }(4 \text { th, } \\
5^{\text {th }, 8 \text { th })}\end{array}$ & I/ 171,223 \\
\hline $\begin{array}{l}\text { Kitāb al-anwār [fì shamā'il } \\
\text { al-Nabī al-Mukhtār?] } \\
\text { (al-Baghawī?) }\end{array}$ & The Prophet's biography & part & III/ 1090 \\
\hline Daf‘ al-Shubbah (al-Ḥușnī) & Qualities of the Prophet & part & $\mathrm{I} / 223$ \\
\hline Kitāb al-Shifā' (al-Nawājī) & Qualities of the Prophet & complete? & II/905 \\
\hline $\begin{array}{l}\text { Qașīdat al-burda al-sharīfa } \\
\text { (al-Būșīīī) }\end{array}$ & $\begin{array}{l}\text { Praise poem for the } \\
\text { Prophet }\end{array}$ & complete & II/905 \\
\hline- & Prayers for the Prophet & part & $\mathrm{I} / 223$ \\
\hline- & $\begin{array}{l}\text { [sayings by the Prophet's } \\
\text { companion Tamīm al-Dārī] }\end{array}$ & part & $\mathrm{IV} / 1556$ \\
\hline $\begin{array}{l}\text { Notes on Hadiyat al-aḥyā' } \\
\text { li-l-amwāt (al-Hakkārī, } \\
\text { d. 1163) }\end{array}$ & Prayers for the dead & $\begin{array}{l}\text { small } \\
\text { notebook/ } \\
\text { part }\end{array}$ & $\mathrm{IV} / 1556$ \\
\hline $\begin{array}{l}\text { Faḍāil sayyidnā Khalīl } \\
\text { al-raḥmān (Ibn 'Asākir) }\end{array}$ & Merits of Abraham/Hebron & part & IV/1556 \\
\hline Faḍāil al-Quds al-sharīf & Merits of Jerusalem & part & IV/ 1556 \\
\hline
\end{tabular}

(Ibn al-Jawzī)

47 Cf. El-Rouayheb, Deep Reading 217. 
TABLE 7.2 Borrowed works (Titles as found in the text plus additions to identify them) (cont.)

\begin{tabular}{|c|c|c|c|}
\hline Title (author) & Subject & Items & Vol./Page \\
\hline Fatḥ al-Bārī (Ibn Ḥajar) & Hadīth, commentary & $\begin{array}{l}\text { parts } \\
\text { (1st, 2nd) }\end{array}$ & $\mathrm{I} / 427$ \\
\hline $\begin{array}{l}\text { Sharh mukhtaṣar șahīḥ } \\
\text { muslim (al-Ḥuṣnī) }\end{array}$ & Hadīth, commentary & part (1st) & II $/ 103^{0}-3^{1}$ \\
\hline- & refutation of Abū Hanīfa & part & $\mathrm{I} / 223$ \\
\hline $\begin{array}{l}\text { Maqbūl al-manqūl } \\
\text { (al-Sībānī?) }\end{array}$ & Law & part (last) & $\mathrm{IV} / 155^{6}$ \\
\hline $\begin{array}{l}\text { [Bidāyat al-muhtāj fì] Sharh } \\
\text { al-Minhāj (Ibn Qāọī Shuhba) }\end{array}$ & Law, commentary & $\operatorname{part}(1 \mathrm{st})$ & $\begin{array}{l}\text { III / 1090, } \\
1098\end{array}$ \\
\hline $\begin{array}{l}\text { 'Ujālat [al-muhtāj ilā tawjīh] } \\
\text { al-minhāj (Ibn al-Mulaqqin) }\end{array}$ & Law, glosses & $\operatorname{part}(1 \mathrm{st})$ & III / 1098 \\
\hline $\begin{array}{l}\text { Ṭabaqāt [al-shāfíiyyāt] } \\
\text { al-Kubrā (al-Subkī) }\end{array}$ & Biographies & $\begin{array}{l}10 \text { quires } \\
\text { (karārīs) } \\
\text { of part } 2\end{array}$ & $\mathrm{I} / 35^{\circ}$ \\
\hline- & Genealogy (ansāb) & part & $\mathrm{I} / 223$ \\
\hline al-Qāmūs (al-Fīrūzābādī) & Lexicography & part & $\mathrm{I} / 337$ \\
\hline
\end{tabular}

The relevance of personal ties is also visible in Ibn Tawq's descriptions of books. For most of the items purchased by Kamāl al-Dīn the copyists Shams al-Dīn al-Qudsī and Ibn Raslān ${ }^{48}$ are identified. In another book loan, he mentions a volume 'in the handwriting of the late Sarī al-Dīn Ibn Qàdị Shuhba, his father's Sharh al-Minhāj' and the 'Kitāb al-anwār in the handwriting of the author's son'. Direct transmission within a family appears to have contributed to a work's devotional value. Yet, these connections mattered beyond faithfulness to an original text:

I delivered the first juz' (part, volume, quire) of the Sharh mukhtașar sahị Muslim (commentary on an abridgement of a hadith collection) by the Sufi shaykh Taqī al-Dīn al-Huṣnì [d. 829] - may God return some of his baraka to me, my children and whom else I love - in the handwriting of shaykh Muhibb al-Dīn al-Ḥuṣnī’s son, Shams al-Dīn Muhammad to the

48 Perhaps identical with Shihāb al-Dīn Aḥmad Ibn Arslān (d. 1440), an important Sufi shaykh in Mamluk Syria; Ephrat D., "The Shaykh, the Physical Setting and the Holy Site: The Diffusion of the Qādirī Path in Late Medieval Palestine", Journal of the Royal Asiatic Society 19,11 (2009) 1-20. 
zāwiya at the Khān al-Huṣnī close to the Muṣallā [square]. It was with me for almost ten months. ${ }^{49}$

Not only was this book written by one and copied by another member of the Hușnī family, it also rested in the Sufi convent founded by one of its members. Ibn Tawq valued the book highly not only for its content but also as a host of baraka, a term which comprises both a person's continued spiritual presence and the blessings that presence could bestow upon other people. The devotional value of a book was thus not only enshrined in the text but in the object itself. The transmission of baraka depended on direct interaction between people - and apparently between people and books. Much as with shaykh Ma'rüf's honeypot, a book could store baraka of its creator (either author or scribe). A much earlier example of this belief is that of Abū 'Umar (d. 1210), eponym of the above-mentioned madrasa. He would perform prayers on his doorstep to safeguard his neighbours' houses, and the Qurān copies he produced 'were known to convey baraka [blessings] into the homes of those who held them. ${ }^{50}$ Ibn Tawq's admission that he had kept this commentary for several months indicates that a similar value was still ascribed to books as carriers of baraka by his time.

Thus, even fragmentary books could become precious items, and loans seem to have concerned mostly partial works. Ibn Țawq usually uses the term $j u z^{\prime}$, which could mean anything from a quire to a full section (chapter: $b \bar{a} b$, fașl) of a text to a complete manuscript or a volume of a larger work [see table 2]. In contrast to the items sold, these appear not to have been bound (mujallad or bi-jild/julüd) but circulated in smaller units of either quire or section, in response to a widespread demand for these materials, which, as we have seen, was not exhausted with reading. Circulation by juz' allowed one book to be spread out among a larger number of (domestic) users and even enabled the joint investigation of one subject in several works:

I lent from the Turābiyya zāwiya: the beginning of the Sirat Ibn Sayyid alNās [...], the beginning of the Ujälat al-minhāj until the commandments (wașāyā), the beginning of the Sharh al-minhāj by Taqī al-Dīn Ibn Qàdị Shuhba, may God be merciful to the authors and the donors! ${ }^{51}$

49 Ibn Țawq, Al-Tacìq vol. 2, 1030-1031.

$5^{0} \quad$ Talmon-Heller, Islamic Piety 97.

$5^{1} \quad$ Ibn Tawq, Al-Ta'lī vol. 3, 1098. 
With one biography of the Prophet, Ibn Țawq borrowed, allegedly for his own use, two legal works, or at least those parts which dealt with issues of 'purity, prayer, fasting, alms, pilgrimage (the essential acts of worship, 'ibādāt, and invariably the first five books of [any jurisprudential work] ). ${ }^{52}$ It is impossible to say whether he used these works only for himself or also to instruct other members of his household. However, it becomes clear that devotional engagement did not require a whole work, nor for a work to be read in a specific order. Here, the works were approached and collated thematically. It is difficult to assess whether this should be ascribed only to the advanced levels of these specific users or whether it is indicative of wider cultural practices. The practice of borrowing ensured wider access to written materials, albeit under controlled conditions. Within this context, books moved slowly but surely from hand to hand (and from house to house).

\section{5}

\section{Conclusions}

Ibn Țawq's reports on book circulation thus allow a glimpse into practices that connected domestic and other forms and sites of devotion. Books provided believers with access to prayers, praise poems, and debates upon the validity of devotions and ablutions, and at the same time could themselves become venerable objects which connected their users and owners to admirable figures from past generations and offered their blessings upon the new possessor and his household. As has been argued elsewhere, books also became more important as a source of authority on questions related to devotion during this time.

IbnṬawq's reports on book use attest to the importance of Prophetic devotion in his time, a phenomenon that encompasses the above-mentioned dreams and mawlid festivities as well. Books might have been used for recitations of those supplicatory prayers, resulting in an apparition of the Prophet, as well as for the recitation of a mawlid on a festive occasion. And much like an invitation to a mawlid or a wedding in another person's home, the loan of a book relied upon close ties between the people involved. Loaning books allowed for a control similar to that of choosing one's guest list and adhered to established social hierarchies. A book had first to be studied with a master before being used alone correctly: 'if the text remained in the mind, it was a constantly available solace and pleasure..$^{53}$ Only then, domestic devotional book use would, for Ibn Tawq, become an accepted practice.

52 Calder, "Law" 981.

53 Calder, "Law" 989. 
In contrast, al-Jazūlī's Dalāil al-khayrāt enabled a different dimension of devotional book use, in which the book could stand on its own and even include advice about its perusal. This may have 'authorized' domestic book use to a new degree. At the same time, this work often became the core of new collections of texts. ${ }^{54}$ Yet, it should be seen as the most successful proponent of a wider phenomenon. Likewise, those quires that circulated in Ibn Țawq's circles would eventually be codified as a compiled volume (majmü $a)$. These books could take the form of a prayer book, a notebook or a commonplace book, and often also served as a family archive. ${ }^{55}$ One example is a manuscript codex which contains, among other fragments, a partial biographical work by Kamāl al-Dīn's father, a list of his own children and their birth dates, and a teaching certificate for his great-great-grandson. ${ }^{56}$ As several ownership annotations of other descendants of Kamāl al-Dīn indicate, this book - it was hoped - would perpetuate the memory of the family even after their library might be sold (as a whole), dissolved or endowed. In the face of the borrowing practices described by Ibn Tawq, a book was not necessarily out of reach after it was endowed. It did not necessarily mean that one could not read or even keep them in one's home. Whereas it is difficult to establish which books were written in domestic settings, it is clear that they were used there. In fact, the memoria functions of books can only be understood against the background of their circulation between private and endowed libraries and a wider readership. A book was a tangible object that connected one's present to the great figures of the past or to one's forefathers - and promised to offer the same for oneself in the future. This was not to be achieved by storing it away. Its value was realized only by its future readers and copyists. Another pious or scholarly owner's or user's inscription on its pages would prove the worth of its contents as well as add to the baraka - and thus the value - of the book.

Not only with regard to their importance for domestic devotion, books should therefore be studied as material objects embedded in diverse practices, not purely as texts. The thousands of collective manuscripts which survive in the Arabic language alone bespeak the widespread investment of time, money, and knowledge that went into the selection and compilation of collective manuscripts in Islamicate societies - and while the preservation of

54 See, for example, Tokyo, Daiber Collection, Ms 334: several prayers and a list of al-Jazūlī's teachers are added to the Daläil.

55 These books often seem to have had similar purposes as early modern English household books; cf. Marotti A.F. - May S.W., Ink, Stink Bait, Revenge, and Queen Elizabeth: A Yorkshire Yeoman's Household Book (Ithaca - London: 2014) in particular 7-12.

$5^{6}$ Universitätsbibliothek Leipzig, ms Vollers $678<\mathrm{http}$ //www.refaiya.uni-leipzig.de/ receive/RefaiyaBook_islamhs_oooo3007> (last accessed 16 Oct. 2015). 
knowledge was one important goal, the compilation of older 'original' texts also attests to a person's creativity and originality in his own engagement with God and the world. Through systematic explorations of these textual corpora, investigations into the exciting domain of domestic devotions could thus bear additional benefits for the field at large, making these sources accessible to a wider scholarship.

\section{Bibliography}

Abou-Khatwa N., "An Ode to Remember: The Burda of al-Busiri in Cairene Ottoman Houses", in Kane B. (ed.), Creswell Photographs Re-examined: New Perspectives on Islamic Architecture (Cairo: 2009) 43-69.

Bray J., "The Family in the Medieval Islamic World", History Compass 9 (2011) 731-742.

Hanna N., "Culture in Ottoman Egypt", in Daly M. (ed.), The Cambridge History of Egypt, 2 vols. (Cambridge: 1998) vol. 2, 87-112.

Hirschler K., Medieval Damascus: Plurality and Diversity in an Arabic Library: The Ashrafiya Library Catalogue (Edinburgh: 2016).

Hirschler K., The Written Word in the Medieval Arabic Lands: A Social and Cultural History of Reading Practices (Edinburgh: 2012).

Ibn al-Arabī Muhyīddīn, The Seven Days of the Heart. Awräd Al-usbǚc (Wird): Prayers for the Nights and Days of the Week, trans. P. Beneito - S. Hirtenstein (Oxford: 2008). Ibn Ṭawq Shihāb al-Dīn Aḥmad, Al-Tálīq. Yawmiyyāt Shihāb al-Dīn Ahmad Ibn Ṭawq. Mudhakkirāt kutibat bi-Dimashq fì awākhir al-'ahd al-mamlūkī, ed. J. al-Muhājir, 4 vols. (Damascus: 2000-2007).

Katz J.G., Dreams, Sufism, and Sainthood: The Visionary Career of Muhammad alZawâwî̀ (Leiden - New York: 1996).

Katz M., The Birth of the Prophet Muhammad: Devotional Piety in Sunni Islam (London: 2007)

Katz M., Prayer in Islamic Thought and Practice (Cambridge: 2013).

Katz M., Women in the Mosque: A History of Legal Thought and Social Practice (New York: 2014).

Lal R., Domesticity and Power in the Early Mughal World (Cambridge: 2005).

Lewicka P., Food and Foodways of Medieval Cairenes: Aspects of Life in an Islamic Metropolis of the Eastern Mediterranean (Leiden: 2011).

Makdisi G., "The Diary in Islamic Historiography: Some Notes", History and Theory 25, 2 (1986) $173-185$.

Marcus A., "Privacy in Eighteenth-Century Aleppo: The Limits of Cultural Ideals", International Journal of Middle-Eastern Studies 18, 2 (1986) 165-183. 
Padwick C.E., Muslim Devotions: A Study of Prayer-Manuals in Common Use (London: 1961).

Peirce L., The Imperial Harem: Women and Sovereignty in the Ottoman Empire (New York: 1993).

Sadan J., "New Materials Regarding Purity and Impurity of Books in Islam in Comparison with Judaism. Al-Burzulī and Other Muslim Scholars on Defiled Parchment, Papyrus and Paper", Jerusalem Studies in Arabic and Islam 33 (2007) 193-218.

Talmon-Heller D., Islamic Piety in Medieval Syria: Mosques, Cemeteries and Sermons under the Zangids and Ayyubids (1146-1260) (Leiden - Boston: 2007).

Witkam J.J., "The Battle of the Images: Mekka vs. Medina in the Iconography of the Manuscripts of al-Jazūlī's Dalāil al-Khayrāt", in Pfeiffer J. - Kropp M. (eds.), Theoretical Approaches to the Transmission and Edition of Oriental Manuscripts: Proceedings of a Symposium held in Istanbul, March 28-30, 2001 (Beirut: 2007) 67-82, 295-300.

Wollina T., "Ibn Țawq's Ta'līq. An Ego-Document for Mamlūk Studies", in Conermann S. (ed.), Ubi Sumus? Quo Vademus? Mamluk Studies - State of the Art, Mamluk Studies 3 (Göttingen: 2013) 337-362. 